\title{
Dipetalonema viteae (Filarioidea) : development of the infective larvae in micropore chambers implanted into normal, infected and immunized jirds*
}

\author{
M. TANNER AND N. WeISS \\ Swiss Tropical Institute, CH-40j1 Basle, Switzerland
}

\begin{abstract}
Using a micropore chamber technique, larval development of Dipetalonema viteae has been followed in jirds (the natural host), hamsters and mice (Gass et al., 1979). Larval development was inhibited in the mouse, an insusceptible host, when this was previously sensitized with live third-stage larvae (L3) (GAss et al., 1979). L3 no longer moulted to the fourth stage (L4). The inhibition of larval development correlated with the appearance of antibodies specific to the cuticle of L3. As in the sera of jirds infected with $D$. viteae, antibodies specific to the cuticle of $\mathrm{L} 3$ and L4 can also be detected (WeIss \& TANNER, 1981); larval development was also examined in micropore chambers implanted into normal, infected and immunized jirds.
\end{abstract}

\section{Material \& Methods}

The filarial parasite, $D$. viteae, was cyclically kept in the jird, Meirones unguiculatus, and the tick, Ornithodorus moubata. L3 were isolated under sterile conditions exactly as described recently (Gass et al., 1979). Micropore chambers with 5.0 and $0.4 \mu \mathrm{m}$ pore size membranes (Nucleopore Corp.) were assembled, loaded with $30 \mathrm{~L} 3$ and implanted subcutaneously into jirds as already described (Gass et al., 1979). Normally a jird received one $5.0 \mu \mathrm{m}$ chamber or, in some experiments, a 5.0 and a $0.4 \mu \mathrm{m}$ chamber simultaneously. Chambers were implanted into jirds two weeks after a previous infection with live L $3(1 \times 125$ or $5 \times 25)$ or after the immunization with $1 \times 125$ dead $(3 \times$ freeze-thawed) or $1 \times 125$ irradiated L3 $(34 \mathrm{krad}, 60 \mathrm{Co})$. Age-matched uninfected jirds served as controls. Two weeks after the implantation, the chambers were removed, the recovered worms were measured (GASs et al., 1979) and the mortality (number of implanted L.3 minus number of recovered motile worms as percentage) was assessed. All the data were recorded separately for each chamber and then pooled for evaluation as described in Gass et al. (1979). Antibodies to the cuticle of L3 and L4 were detected by the indirect immunofluorescent antibody test (IFAT) as described in WeIss \& TANNeR (1981).

\section{Results \& Discussion}

Table I summarizes the results of four independent experiments. L3 developed to L4 inside $5 \mu \mathrm{m}$ chambers in uninfected controls within two weeks. The median length varied between 2.3 and $3.6 \mathrm{~mm}$ in the four experiments. These results as well as the mortality data (with the exception of Expt. III) are consistent with earlier results on larval development within micropore chambers implanted into jirds (GASS et al., 1979).
A significant larval growth inhibition was observed within $5.0 \mu \mathrm{m}$ chambers implanted into jirds which had been previously infected with live L3 ( $1 \times 125$ or $5 \% 25$, Expts. I-IV). The median lengths were 1.3 to $1.9 \mathrm{~mm}$ which means that most larvae did not complete their moult to L4. In addition, larval mortality was, with one exception (Expt. III), significantly higher. Immunization of jirds with irradiated L3 also resulted in a significant larval growth inhibition (Expt. III). In this respect it is noteworthy that $34 \mathrm{krad}$-irradiated L3 can complete their moult to L4 in micropore chambers (Fig. 1). Inoculated into hamsters, irradiated $\mathrm{L} 3$ never reached the fertile adult stage. Higher irradiation doses $(51 \mathrm{krad})$ reduce the percentage of L3 moulting to L4 (Fig. 1). The mortality among 34 and 51 krad irradiated L3 within micropore chambers was only slightly higher than that of the non-irradiated controls. This is consistent with similar experiments described for Dirofilaria immitis (see WoNG et al., 1974), for Brugia spp. (see RAMACHANDRAN, 1970; OOTHUMAN et al., 1978, 1979) and for Litomosoides carinii (see RAo et al., 1977). The immunization of jirds with dead larvae did not provoke any larval growth inhibition (Expt. II).

Inhibited larval development correlated with the detection of antibodies specific to the cuticle of L3 and L4, i.e. the infection of jirds with live L3 and the immunization with irradiated L3 provoke the production of anticuticular antibodies. The immunization with dead L3, however, only stimulated antibodies against somatic antigens ( $\mathrm{cf}$ also WEISS \& TANNER, 1981).

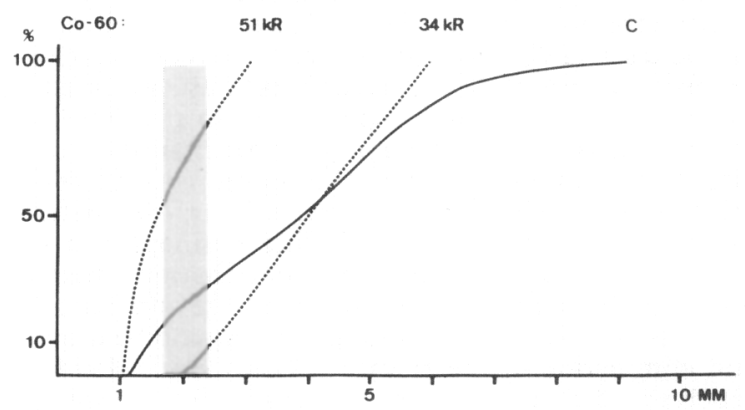

Fig. 1. Cumulative frequency distribution of the length of normal (C) and irradiated larvae from 5.0 $\mu \mathrm{m}$ micropore chambers two weeks after the implantation into uninfected jirds. The shaded area indicates the range of the third moult.

*Supported by the Swiss National Science Foundation grant No. 3.267.78 
Table I-Larval development in micropore chambers implanted into normal, infected and immunized jirds

\begin{tabular}{|c|c|c|c|c|c|c|c|c|}
\hline Experiment & Jird & $\begin{array}{l}\text { Chamber } \\
\text { pre size } \\
\mu \mathrm{m}\end{array}$ & $\mathrm{Na}$ & $\begin{array}{c}\text { Mortality } \\
0 \\
0\end{array}$ & $\begin{array}{c}\text { Number of } \\
\text { larvae } \\
\text { examined }\end{array}$ & median & $\begin{array}{l}\text { Length (mm) } \\
(95 \% \text { confidence }\end{array}$ & limit) \\
\hline I & $\begin{array}{l}\text { Controls } \\
1 \times 125 \text { L3 live } \\
5 \times 25 \text { L3 live }\end{array}$ & $\begin{array}{l}5 \cdot 0 \\
5 \cdot 0 \\
5 \cdot 0\end{array}$ & $\begin{array}{l}5 \\
7 \\
4\end{array}$ & $\begin{array}{l}55 \\
77^{\star \star \star} \\
82^{\star \star \star}\end{array}$ & $\begin{array}{l}64 \\
47 \\
26\end{array}$ & $\begin{array}{l}3 \cdot 60 \\
1 \cdot 49 \\
1 \cdot 37\end{array}$ & $\begin{array}{l}(3 \cdot 23-3 \cdot 78) \\
(1 \cdot 49-1 \cdot 55) \\
(1 \cdot 30-1 \cdot 43)\end{array}$ & $\begin{array}{l}\mathrm{A} \\
\mathrm{B} \\
\mathrm{C}\end{array}$ \\
\hline II & $\begin{array}{l}\text { Controls } \\
1 \times 125 \text { L } 3 \text { live } \\
1 \times 125 \text { L } 3 \text { dead }\end{array}$ & $\begin{array}{l}5 \cdot 0 \\
5 \cdot 0 \\
5 \cdot 0\end{array}$ & $\begin{array}{l}4 \\
6 \\
6\end{array}$ & $\begin{array}{l}21 \\
66^{\star \star} \\
54^{\star \star}\end{array}$ & $\begin{array}{r}143 \\
40 \\
82\end{array}$ & $\begin{array}{l}2 \cdot 85 \\
1 \cdot 49 \\
2 \cdot 54\end{array}$ & $\begin{array}{l}(2 \cdot 48-3 \cdot 23) \\
(1 \cdot 49-1 \cdot 61) \\
(1 \cdot 61-3 \cdot 23)\end{array}$ & $\begin{array}{l}\mathrm{D} \\
\mathbf{E} \\
\mathrm{F}\end{array}$ \\
\hline III & $\begin{array}{l}\text { Contrels } \\
1 \times 125 \text { L3 live } \\
1 \times 125 \text { L3 34krad }\end{array}$ & $\begin{array}{l}5 \cdot 0 \\
0 \cdot 45 \\
5 \cdot 0 \\
0 \cdot 45 \\
5 \cdot 0 \\
0 \cdot 45\end{array}$ & $\begin{array}{l}8 \\
6 \\
3 \\
4 \\
5 \\
7\end{array}$ & $\begin{array}{l}72 \\
67 \\
71 \\
48 \\
79 \\
60\end{array}$ & $\begin{array}{l}63 \\
58 \\
26 \\
56 \\
32 \\
80\end{array}$ & $\begin{array}{l}3 \cdot 72 \\
2 \cdot 17 \\
1 \cdot 86 \\
2 \cdot 24 \\
1 \cdot 37 \\
1 \cdot 68\end{array}$ & $\begin{array}{l}(3 \cdot 23-4 \cdot 09) \\
(1 \cdot 80-2 \cdot 36) \\
(1 \cdot 30-2 \cdot 11) \\
(1 \cdot 80-3 \cdot 23) \\
(1 \cdot 24-1 \cdot 74) \\
(1 \cdot 55-1 \cdot 92)\end{array}$ & $\begin{array}{l}\mathrm{G} \\
\mathrm{H} \\
\mathrm{I} \\
\mathrm{K} \\
\mathrm{L} \\
\mathrm{M}\end{array}$ \\
\hline IV & $\begin{array}{l}\text { Controls } \\
1 \times 125 \text { L3 live }\end{array}$ & $\begin{array}{l}5 \cdot 0 \\
0 \cdot 45 \\
5 \cdot 0 \\
0 \cdot 45\end{array}$ & $\begin{array}{l}6 \\
7 \\
8 \\
7\end{array}$ & $\begin{array}{l}47 \\
37 \\
60^{\star} \\
65^{\star \star}\end{array}$ & $\begin{array}{r}96 \\
133 \\
96 \\
74\end{array}$ & $\begin{array}{l}2 \cdot 30 \\
1 \cdot 55 \\
1 \cdot 30 \\
1 \cdot 37\end{array}$ & $\begin{array}{l}(1 \cdot 61-2 \cdot 73) \\
(1 \cdot 49-1 \cdot 61) \\
(1 \cdot 24-1 \cdot 37) \\
(1 \cdot 30-1 \cdot 37)\end{array}$ & $\begin{array}{l}\mathrm{N} \\
\mathrm{O} \\
\mathrm{P} \\
\mathrm{Q}\end{array}$ \\
\hline 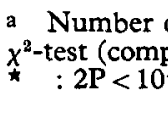 & $\begin{array}{l}\text { hambers examined } \\
\mathrm{d} \text { to the dor-espond } \\
\star: 2 \mathrm{p}<10^{-3}, \star \star \star\end{array}$ & $\begin{array}{l}\text { control) } \\
10^{-1}\end{array}$ & & \multicolumn{2}{|c|}{$\mathrm{U}$-(rank) test } & $\begin{array}{l}P<0 \cdot 05 \\
P<10^{-2} \\
P<10^{-4}\end{array}$ & $\begin{array}{l}: \mathrm{G}-\mathrm{H}, \mathrm{I}-\mathrm{K}, \mathrm{L}-\mathrm{M} \\
: \mathrm{A}-\mathrm{B}, \mathrm{A}-\mathrm{C}, \mathrm{E}-\mathrm{F} \\
: \mathrm{D}-\mathrm{E}, \mathrm{G}-\mathrm{I}, \mathrm{G}-\mathrm{L}, \\
\mathrm{N}-\mathrm{P}, \mathrm{O}-\mathrm{Q}\end{array}$ & $\mathrm{N}-\mathrm{O}$ \\
\hline
\end{tabular}

In order to get information on the mechanisms mediating larval growth inhibition, $0.4 \mu \mathrm{m}$ chambers were implanted. These chambers prevent host cell immigration. Thus, the effect of antibodies alone can be measured. Experiments III and IV show that larval growth inside $0.4 \mu \mathrm{m}$ chambers is significantly inhibited also within uninfected controls when compared with the corresponding $5.0 \mu \mathrm{m}$ chambers. Nevertheless, the moult to L4 could still take place in such $0.4 \mu \mathrm{m}$ chambers in controls (Expt. III). This was also the case within $0.4 \mu \mathrm{m}$ chambers implanted into previously infected (125 live L 3 ) or immunized (125 $34 \mathrm{krad} \mathrm{L.3)} \mathrm{jirds,} \mathrm{while} \mathrm{larval} \mathrm{development}$ in the corresponding $5.0 \mu \mathrm{m}$ chambers was significantly inhibited (Expt. III). However, a replicate experiment (IV) was inconsistent. Larval development within $0.4 \mu \mathrm{m}$ chambers was inhibited in controls to the same proportion as in previously infected jirds. Thus it is not yet clear if antibodies alone are responsible for the observed growth inhibition. Preliminary studies in vitro with peritoneal exudate cells-including eosinophil enriched cell populations-in combination with anticuticular antibodies did not promote adherence of cells to L3 and subsequent immobilization and elimination of the larvae. WoNG et al. (1974) reported the appearance of antibodies specific against L 3 in beagle dogs immunized with irradiated L 3 of $D$. immitis. There appeared to be some evidence of correlation between L3 antibody levels and the degree of resistance of these immunized dogs.

The significance of our present results in respect to protection following challenge or superinfections is currently being investigated.

\section{References}

Gass, R. F., Tanner, M. \& Weiss, N. (1979). Development of Dipetalonema viteae third-stage larvae (Nematoda: Filarioidea) in micropore chambers implanted into jirds, hamsters, normal and immunized mice. Zeitschrift fur Parasitenkunde, 61, 73-82.

Oothuman, P., Denham, D. A., McGreevy, P. B. \& Nelson, G. S. (1978). Studies with Brugia pahangi. 15. Cobalt 60 irradiation of the worm. Fournal of Helminthology, 52, 121-126.

Oothuman, P., Denham, D. A., McGreevy, P.B., Nelson, G. S. \& Rogers, R. (1979) Successful vaccination of cats against Brugia pahaing with larvae attenuated by irradiation with 10 krad cobalt 60. Parasite Immunology, 1, 209-216.

Ramachandran, C. P. (1970). Attempts to immunize domestic cats with $\mathrm{X}$-irradiation infective larvae of sub-periodic Brugia malayi. 1. Parasitological aspects. Southeast Asian fournal of Tropical Medicine and Public Health, 1, 78-92.

Rao, G. Y. V. B., Mehta K. \& Subrahmanyam D. (1977). Litomosoides carinii: effect of irradiation on the development and immunogenicity of the larval forms. Experimental Parasitology, 43, 39-44.

Weiss, N. \& Tanner, M.(1981). Immunogenicity of filarial larvae (Dipetalonema viteae). Transactions of the Royal Society of Tropical Medicine and Hygiene, 75.

Wong, M. M., Guest, M. F. \& Lavoipierre, M. J. (1974). Dirofilaria immitis: Fate and immunogenicity of irradiated infective stage larvae in beagles. Experimental Parasitology, 35, 465-474. 